\title{
Overcoming barriers to providing local produce in school lunches in Vermont
}

\author{
Erin Rochea , Jane M. Kolodinskyb
}

Submitted 11 November 2010 / Accepted 22 March 2011 / Published online 9 June 2011

Citation: Roche, E., \& Kolodinsky, J. M. (2011). Overcoming barriers to providing local produce in school lunches in Vermont. Journal of Agriculture, Food Systems, and Community Development, 1(3), 89-97. http://dx.doi.org/10.5304/jafscd.2011.013.012

Copyright (C) 2011 by New Leaf Associates, Inc.

\begin{abstract}
Vermont is a leader in connecting its agricultural sector to its education system in order to provide schoolchildren with fresh, local produce. Adopting farm to school programs is not easier in Vermont; in fact, school administrators and food service directors cite the same barriers as can be found throughout the country. However, some communities in Vermont have worked hard to address these barriers and are succeeding in getting fresh local foods into their schools' meals. This article reviews common barriers and challenges to successful farm to school programs and describes some of the creative ways that schools in Vermont have addressed them.
\end{abstract}

Corresponding author: Erin Roche, tel. +1 (802) 656-1936, fax:

+1 (802) 656-1423, eroche1@uvm.edu

a University of Vermont, Center for Rural Studies, 146

University Place, Burlington, Vermont, 05405 USA

b University of Vermont, Department of Community Development and Applied Economics, 146 University Place, Burlington, Vermont, 05405 USA

\section{Keywords}

barrier, farm to school, local agriculture, National School Lunch Program, nutrition, school lunch

\section{Literature Review}

In $2008,17 \%$ of children in the United States aged 2 to 19 were at or above the 95 th percentile for body mass index and $31 \%$ were at or above the $85^{\text {th }}$ percentile or considered overweight or obese (Ogden, Carroll, Curtin, Lamb, \& Flegal, 2010). Vermont's rate of $26 \%$ considered overweight or obese is slightly lower (NSCH, 2008; Eaton, Kann, $\&$ Kinchen, 2008) than the national average. This problem has gained national attention. While the cause of obesity is typically an energy imbalance, solving the problem has proven to be complex, as evidenced by the number of solutions put forward with no improvement in the obesity trend. The National School Lunch Program (NSLP), which has been administered by the USDA since 1946, provides an opportunity to ensure that children get at least one healthy meal five days per week. But the quality of these school lunches in terms of both nutrition and calorie availability has been questioned in the popular media as well as by 
scientific research (for example, Crepinsek, Gordon, McKinney, Condon, \& Wilson, 2009).

The American Dietetic Association believes that schools should provide meals high in nutrition to all students (Pilant, 2006). Unfortunately, this is often not the case with school lunches. The NSLP requires that not more than $30 \%$ of lunch calories come from fat, and not more than 10\% of calories from saturated fat. Lunches are required to provide one-third of the Dietary Reference Intake for calories, protein, vitamin $\mathrm{A}$, vitamin $\mathrm{C}$, iron, and calcium (for more information about Dietary Reference Intakes, see Penland, 2006). Each meal must include an entrée, milk, and at least one other item. However, according to the School Nutrition Dietary Assessment Study III (SNDA-III) survey in 2004-2005, an average of 34\% of calories in school lunches came from fat, and only $20 \%$ of the schools met the guideline for fat and only 30\% met the guideline for saturated fat (USDA, 2007).

While most school meals do meet dietary requirements for protein and a variety of essential vitamins and minerals, two-thirds of schools serve lunches that are too high in fat (Crepinsek et al., 2009). Students who participate in the NSLP generally have an increased intake of fat (Gleason \& Suitor, 2003), and this has been an ongoing problem (Dwyer, 1995). Further, school lunches are generally high in sodium and low in fiber (Crepinsek et al., 2009).

Given that school lunches may account for 25\% (or more) of a participating schoolchild's nutrition (USDA, 2010), they are an appropriate place to address childhood obesity. But participation in school lunches varies greatly, especially by household income (Dunifon \& Kowaleski-Jones, 2003; Gleason, 1995). While NSLP lunches may provide more fat than required, one recent study concluded that homemade lunches have more fruit, more energy from sugar, and fewer vegetables (Rees, Richards \& Gregory, 2008).

Policymakers and researchers alike seek solutions to combat childhood obesity and ensure good nutrition. Nationwide, communities are beginning to establish a link between local agriculture and schools as one way to teach children about good nutrition and ensure availability and consumption of more fruits and vegetables. Often referred to as farm to school (FTS) programs, these efforts can include one or more of the following: establishing school gardens; serving fresh, local products in school meals; making food and agriculture-related field trips; having farmers visit schools; teaching curricular units on food and nutrition; and providing professional development for food-service staff. Increasing children's fruit and vegetable intake alone may not be sufficient to address the childhood obesity challenge (Lin \& Morrison, 2002), but it's unlikely that energy balance can be achieved without eating more fruits and vegetables. The United States Department of Agriculture (USDA) has specifically included fruit and vegetable intake as a measure for lowering obesity in children (USDA NIFA, 2011).

Research has shown that FTS programs increase students' intake of fresh fruits and vegetables and can improve their nutrition and knowledge of the food system (Croom, 2005; Graham, Feenstra, Evans, \& Zidenberg-Cherr, 2004; Joshi, Azuma, \& Feenstra, 2008; Joshi \& Beery, 2007; Ohmart \& Feenstra, 2004). Despite the positive effects associated with FTS programs, fewer than $10 \%$ of public schools nationwide have implemented a farm to school program (Farm to School, 2010; NCE, 2008). Narrowly focused school-based interventions generally result in slight impact on childhood obesity and children's food behavior (Sharma, 2006). FTS programs may succeed because when fully implemented they focus not just on a single area of intervention, but also include classroom education and utilize cafeteria, garden, and farm venues (VT FEED, 2010).

According to one estimate, at least one-third of all Vermont public schools have engaged in one or more of the activities described above (VT FEED, 2010). In a recent survey of Vermont schools, $71 \%$ (King, Kolodinsky, Roche, Berlin, Nelson \& Norris, 2009) reported purchasing some local foods for their school lunches. State and local policies play a role in encouraging FTS efforts as 
well. The Vermont Department of Education requires school districts to have a wellness committee (VDE, 2010), and many schools' FTS efforts have arisen from these committees. The Vermont Agency of Agriculture, Food and Markets administers the Rozo McLaughlin FTS grant program (VAAFM, 2009), which has provided grants to more than 40 elementary and secondary schools since 2007 (VAAFM, 2009; VAAFM, 2010). In addition, several mission-based organizations offer technical assistance to school food service in the form of recipe development and distribution, workshops, and professional development.

Why don't more schools adopt these programs? Many barriers obstruct schools' efforts to adopt FTS programs. These barriers may lead one to conclude that while desirable, FTS programs are neither feasible nor sustainable. These barriers have been documented in other research (Berkenkamp, 2006; Izumi, Rostant, Moss, \& Hamm, 2006) and include the higher cost of local produce, lack of training, lack of equipment, logistical challenges, and limited availability of local food. However, some communities in Vermont have sought to overcome these barriers in order to procure fresh, locally produced foods for school meals as well as to contribute to the continued vitality of their mostly rural communities. How are these schools and communities able to overcome these barriers? And can other communities benefit from these solutions?

\section{Applied Research Methods}

This research utilized in-depth qualitative interviews at each school with the person who was most knowledgeable about that school's FTS efforts and programs. In some cases, the school food service director was interviewed, while in others an FTS coordinator was interviewed. Qualitative methods are ideal for this exploratory research to determine not only what barriers exist to getting local foods in the cafeteria, but also to understand how each school addresses these barriers. An interview guide, summarized below, was developed to provide structure and consistency to each interview.
- Current and past states of the FTS program

- Describe school activities that help promote healthy eating.

- Describe the process of implementing each activity.

- Describe challenges to activity implementation.

- Describe any failures of activity implementation.

- Future of FTS program

- Describe how these activities will or will not continue.

- Describe any planned new activities.

- Describe the requirements to sustain these activities.

Schools having some type of FTS activities during the past 10 years were identified and asked to participate by the research team. Efforts were made to interview schools with different FTS activities and program longevity, as well as to represent a broad geographic distribution. In total, 20 interviews were conducted at schools throughout the state. See table 1 for the characteristics of the participating schools. All schools in this study were Vermont public schools and participated in the NSLP.

Interviews were conducted by telephone during March and April 2009, and February and March 2010, by a team of researchers led by the University of Vermont. Each school representative was interviewed only once during the course of the research. The researchers were trained in qualitative interview techniques and used a discussion guide for the semistructured interviews (Trochim, 2006). Content analysis was used to analyze the interview notes. For the purposes of this research, FTS "success" is defined as an ongoing or sustained FTS program. 


\section{Results and Discussion}

Participants were asked to describe any challenges the program faced. Challenges that could be barriers to FTS programs are summarized in table 2. All school staff members interviewed cited at least one of the barriers summarized below. When asked to describe best practices and other ways the school has made its program successful, responses were far more diverse, but can be categorized as addressing one or more of the barriers identified. Quotations regarding best practices and barriers used below are all from interviewees.

As reported in other studies and as shown in table 2, a common barrier to successful FTS programs is the relatively high cost of local foods as compared to commodity alternatives. One school staff member related that "demand for local produce is greater than supply, resulting in higher prices. Large food service doesn't get much of a price break for ordering large quantities from small farmers" when demand is high.

As stated by numerous interviewees, school lunch budgets in Vermont are separate from the rest of the school budget, and the lunch program must cover its own costs for food as well as labor and equipment. Revenue for school lunches comes from three different sources:

(1) Schools are federally reimbursed for the lunches they serve at rates of US $\$ 2.68$ for students qualified for free lunch, US $\$ 2.28$ for students qualified for reduced-price lunch, and US $\$ 0.25$ for all other students' lunches. In addition, schools that serve a student population that is $60 \%$ or more eligible for free or reduced lunches receive a slightly higher reimbursement (USDA, 2010);

(2) The full price of an elementary school lunch in Vermont ranges from US $\$ 1.50$ to US $\$ 2.50$ (as determined from the school lunch menus and interviews); and

(3) Some schools make "à la carte" items such as extra milk, snacks and sandwiches available for purchase in addition to the hot lunch.
Table 1. Summary of Schools $(N=20)$

\begin{tabular}{|c|c|}
\hline & $\begin{array}{c}\text { \# of } \\
\text { schools }\end{array}$ \\
\hline \multicolumn{2}{|l|}{ Rural, urban } \\
\hline Rural & 19 \\
\hline Urban & 1 \\
\hline \multicolumn{2}{|l|}{ Grades } \\
\hline Elementary & 17 \\
\hline Middle/secondary & $6^{a}$ \\
\hline \multicolumn{2}{|c|}{ Farm to school program experience } \\
\hline Less than 1 year & 6 \\
\hline $1-2$ years & 8 \\
\hline $2-3$ years & 4 \\
\hline More than 3 years & 2 \\
\hline \multicolumn{2}{|c|}{ Percent of students eligible for free or reduced lunch ${ }^{b}$} \\
\hline Less than $50 \%$ & 13 \\
\hline $50 \%$ or more & 7 \\
\hline \multicolumn{2}{|c|}{ Number enrolled (2009-2010) ${ }^{c}$} \\
\hline$<100$ students & 4 \\
\hline $100-300$ students & 8 \\
\hline $301-500$ students & 4 \\
\hline $501+$ students & 4 \\
\hline
\end{tabular}

a Some schools included both elementary and secondary levels. b Vermont Department of Education. (2011). Food and Nutrition Management Eligibility Report for Fiscal Year 2011. Retrieved from http://education.vermont.gov/new/html/data/enrollment.html c Vermont Department of Education (2010). Fiscal Year 2010 Public School Enrollment Report, Table 4. Retrieved from http://www.education.vermont.gov/new/pdfdoc/pgm_nutrition/sch ool_nutrition/pubs_resources/educ_sch_nutrition_fr_report.pdf

Table 2. Summary of Barriers to Providing Fresh, Local Foods in School Lunches $(N=20)$

\begin{tabular}{lc}
\hline Cost of labor and/or increased time & $\begin{array}{c}\text { \# of } \\
\text { mentions }^{\text {a }}\end{array}$ \\
Higher cost of local food & 10 \\
Storage and/or equipment & 8 \\
Availability and/or transportation of local food & 4 \\
Training and skills for food-service staff & 2 \\
Other & 1 \\
\hline Total responses & 4 \\
\hline
\end{tabular}

${ }^{a}$ More than one mention per participant was permitted. 
These three revenue streams may be sufficient to cover the costs of a hot lunch prepared from canned goods and commodity foods. However, this revenue does not result in the budgetary flexibility that would allow purchase of higher cost items such as fresh, local produce or meat.

Schools with sustained FTS programs, however, have found creative means to provide local foods in their lunches. Table 3 provides a summary of these approaches. Involvement from the broader community was a common approach to procuring local foods. Several schools have planted gardens and use produce from the garden to "supplement meals with tossed salad offered three times a week." One school reported "planting 12 blueberry bushes" in order to add this popular fruit to lunch menus. School gardens, especially in a northern climate, require assistance from the community during the summer months. One school "had a

\section{Table 3. Summary of Solutions ${ }^{a}$}

\begin{tabular}{|c|c|}
\hline Barrier type & Solutions \\
\hline $\begin{array}{l}\text { Cost of labor and/or } \\
\text { increased time }\end{array}$ & $\begin{array}{l}\text { - } \text { Community fundraisers } \\
\text { - Purchase of processing equipment } \\
\text { - Parent Teacher Organization (PTO) fundraisers } \\
\text { - Sale of food service products } \\
\text { - Parent and school board support } \\
\text { - FTS coordinator position }\end{array}$ \\
\hline Higher cost of local food & $\begin{array}{l}\text { - School garden with community support } \\
\text { - Community fundraiser } \\
\text { - Proceeds from concession sales } \\
\text { - PTO fundraisers } \\
\text { - Sale of food service products } \\
\text { - Purchase of "seconds" } \\
\text { - Form buying cooperatives and networks }\end{array}$ \\
\hline Storage and/or equipment & $\begin{array}{l}\text { - State grant program } \\
\text { - PTO fundraisers } \\
\text { - Community fundraisers } \\
\text { - Purchase of freezers }\end{array}$ \\
\hline $\begin{array}{l}\text { Availability and } \\
\text { transportation of local food }\end{array}$ & $\begin{array}{l}\text { - Form local distribution networks } \\
\text { - Build farmer relationships } \\
\text { - Community participation } \\
\text { - Technical assistance provided by nonprofit } \\
\text { - FTS coordinator position }\end{array}$ \\
\hline $\begin{array}{l}\text { Training and skills for food } \\
\text { service staff }\end{array}$ & $\begin{array}{l}\text { - State grant program } \\
\text { - Technical assistance provided by nonprofit }\end{array}$ \\
\hline
\end{tabular}

${ }^{a}$ Examples of each solution are explained within the results section. spring vegetable garden the spring before for the meal program" but had not addressed summer garden maintenance and thus could not sustain this program. At the other extreme, one school took its school garden to a new level by having a "[maple] sugar house with an attached greenhouse" at the school.

Many schools reported holding community fundraisers to raise money to purchase from local farms. These fundraisers take many forms. The "farm fest" is a fundraiser for FTS programs that invites the whole community to participate.

Another school uses athletic event concession sales to its advantage by using "basketball snack proceeds to put into money for the meal program." In several schools where the parental community is especially supportive, the Parent Teacher Organization hosts fundraisers or uses fundraiser proceeds to purchase local foods for school lunches. Another approach is for schools to sell what they produce, with one school making and selling salsa while another uses "maple syrup produced by eighth graders [which] is sold to the school as a commodity."

Lastly, schools take advantage of the most affordable local produce. From "using apple drops to make applesauce" and gleaning produce at local farms to "forming buying cooperatives" and nonprofit "food distribution networks," these schools are obtaining fresh, local produce for school lunches. The drawback is that raw, unprocessed food typically requires more time on the part of food service employees. Many food service staff require additional training or skills to learn how to use unprocessed ingredients. It may take longer for a food service manager to identify a source for an ingredient than just calling a distributor. Preparing and processing the ingredients takes 
time as well. A food service director candidly explained, "They had to get me a helper, because I just couldn't [get] it all done. I told them if you want me to do this, I need help. And [now] she's busy preparing fresh food for me." Since many food service workers are paid an hourly wage, the cost of this additional time affects the lunch budget; as one food service director stated, "You just can't be a one-[wo]man band and process fresh fruits and vegetables." Some food service directors take this responsibility to heart because, "The processing is definitely time-consuming. I spend weekends and nights when it's processing [time]. I don't get paid for it. I volunteer because there's just not enough time during the day."

As one school food service director commented, "If you know how to do it [cook], it's cheaper to make your own." But for most schools, food service staff needed new skills before they could effectively incorporate fresh produce. "We were doing brown-and-serve lunch [before] and that was what the staff was comfortable with. We had to start from the ground up. We had cutting boards and knives, needed food processing equipment, and ServSafe ${ }^{\circledR}$ [food safety] training, and health and safety training."

To overcome this barrier, one school staff member states that training received from a nonprofit "was key because they needed outside professionals to get advice from. They are not fancy cooks and are not used to cooking for large numbers with fresh ingredients." Another school staff member reiterated, "Staff training is important for making the program sustainable." In addition to cooking skills, food service staff members need training to source local ingredients. One nonprofit that acts as a regional FTS program coordinator recalls, "We had to train the cooks on how to order from the farmers. It's not one-stop shopping like they're used to. We had to develop an ordering protocol. We had the cooks, farmers and supervisor all meet together to develop this."

In fact, many schools interviewed that had ongoing FTS programs created an FTS coordinator position, either on staff or on a contractor basis.
This coordinator may provide training, logistical coordination, and support, as well as organize fundraisers and write grants. Overall, schools have used a variety of approaches to address logistical concerns. One school crafted an agreement for a local store to serve as "drop-off or collection point for farm product for schools" until food service staff could pick it up, essentially creating its own local food hub. Another school summed up a common sentiment with, 'We've worked hard to make purchasing more efficient [by knowing what to make ourselves and what to buy premade]."

Especially in a northern climate, even if a school can address challenges of cost and logistics, timing and availability continue to be a barrier to using local produce in school lunches. One school addressed this by "using grant money to buy a freezer for freezing vegetables." Several schools have taken advantage of having committed community members and relied on "families to sign up through the summer" to maintain and harvest the garden. This "gets families from each grade to make a commitment to weed, water, and harvest from the school garden throughout the summer." However, this is not feasible for all schools; one school staff member believes that "Gardens are too labor-intensive in the summer months."

These exploratory findings may provide some insight for practitioners seeking to address the many barriers to getting more fresh produce into school meals, which is admittedly just one aspect of FTS. While, as this research shows, there is no standard approach that every school can use, the diversity of solutions described may offer some guidance. School budgets are carefully scrutinized, and many of the barriers to FTS are directly or indirectly related to costs. Addressing these barriers without increasing the school's budget may be necessary to support efforts at procuring fresh, local produce.

\section{Conclusions}

Getting fresh, local produce into school lunches is one strategy that some communities have adopted to improve student nutrition and reduce obesity. 
But the barriers to getting fresh, local foods into school meals often seem daunting. Some schools, however, have been able to succeed despite the many barriers. While there is no one "recipe" for success with an FTS program, these schools have provided a list of "ingredients" that may be used by others. All the solutions described in the results have required hard work and dedication throughout the school community, and while these schools have been able to address barriers, they will need to keep working hard to yield continued success. Anecdotally, it seems that the one common element among these schools is the presence of an FTS champion, in some cases a teacher, parent, administrator, or food service worker, who is determined to make a change.

This applied research has several limitations and also makes clear several areas for future research. This research focused on the nutritional outcomes of FTS programs; it made no effort to consider barriers or solutions to educational or community outcomes. While subjects talked generally about the higher cost of local food, it was beyond the scope of this research project to quantify the cost difference or to determine how much of the costs are direct food costs compared with labor and equipment expenses. Research is needed to examine whether the improved quality of FTS meals translates to changes in food quality outside of school (e.g., meals at home). Further, do school gardens, because of their reliance on parental support for summer garden maintenance, result in more increased school lunch participation or broad nutrition changes in meals at home?

Childhood obesity rates continue to climb (CDC, 2009; Eaton, Kann, \& Kinchen, 2008; Ogden, Carroll, \& Flegal, 2008), and getting kids to eat their vegetables has long been a challenge (Lorson, Melgar-Quiñonez \& Taylor, 2009; Muñoz, KrebsSmith, Ballard-Barbash, \& Cleveland, 1997; USDA, 2005). Communities struggle, but the results of our research suggest that they can make progress using creative solutions to address barriers inherent in providing healthy, calorie-appropriate, nutrientdense meals to students.
Fresh produce alone may not address the number of calories kids consume, but like an ingredient in a recipe, when combined with increased cooking skills and less reliance on processed foods, the result may be greater than the sum of the parts and over time may help shape better nutritional preferences among children and improve their health outcomes.

\section{References}

Berkenkamp, J. (2006). Making the farm/ school connection: Opportunities and barriers to greater use of locally-grown produce in public schools. Prepared for the Department of Applied Economics at University of Minnesota.

Centers for Disease Control and Prevention (CDC). (2009). NHANES data on the prevalence of overweight among children and adolescents: United States, 2003-2004. National Center for Health Statistics. Retrieved from http://www.cdc.gov/nchs/products/ pubs/pubd/hestats/overweight/overwght_child_ 03.htm

Crepinsek, M. K., Gordon, A. R., McKinney, P. M., Condon, E. M., \& Wilson, A. (2009). Meals offered and served in US public schools: do they meet nutrient standards? Journal of American Dietetics Association, 109(2), S31-S43. doi:10.1016/j.jada.2008.10.061

Croom, E. (2005). Farm to school programs as leverage points to changing the school food system (Unpublished master's thesis). University of Vermont, Burlington, Vermont.

Dunifon, R., \& Kowaleski-Jones, L. (2003, March). The influences of participation in the national School Lunch program and food insecurity on child wellbeing. The Social Service Review, 77, 79-92. doi:10.1086/345705

Dwyer, J. (1995). The school nutrition dietary assessment study. American Journal of Clinical Nutrition, 61 (supplement), 173S-177S.

Eaton, D. K., Kann, L., \& Kinchen, S. (2008). Youth risk behavior surveillance - United States 2007. Centers for Disease Control and Prevention. Retrieved from http://www.cdc.gov/healthyyouth/ yrbs/pubs_mmwr.htm

Farm to School (2010). Statistics. Retrieved from http://www.farmtoschool.org

Gleason, P. M., \& Suitor, C. W. (2003). Eating at school: How the National School Lunch Program affects children's diets. American Journal of Agricultural Economics, 85(4), 1047-1061. doi:10.1111/1467-8276.00507 
Gleason, P. M. (1995). Participation in the National School Lunch program and the School Breakfast program. American Journal of Clinical Nutrition 61 (supplement), 213S-220S.

Graham, H., Feenstra, G., Evans, A. M., \& ZidenbergCherr, S. (2004). Davis school program supports life-long healthy eating habits in children. California Agriculture, 58(4): 200-205. doi: $10.3733 / \mathrm{ca} . \mathrm{v} 058 \mathrm{n} 04 \mathrm{p} 200$

Izumi, B. T., Rostant, O. S., Moss, M. J., \& Hamm, M. W. (2006). Results from the 2004 Michigan Farmto-School Survey. Journal of School Health, 76(5), 169-174. doi:10.1111/j.1746-1561.2006.00090.x

Joshi, A., Azuma, A. M., \& Feenstra, G. (2008). Do farm-to-school programs make a difference? Findings and future research needs. Journal of Hunger \& Environmental Nutrition 3(2), 229-246. doi:10.1080/19320240802244025

Joshi, A., \& Beery, M. (2007). A growing movement: $A$ decade of farm to school in California. Center for Food \& Justice, The Urban \& Environmental Policy Institute, Occidental College, 1-31.

King, B., Kolodinsky, J. M., Roche, E., Berlin, L., Nelson, A. and Norris, K. (March 2009). Farm-toSchool Programs build social equity in Vermont. Paper presented at the Farm to Cafeteria Conference of Farm to School, Portland, Oregon.

Lin, B. H., \& Morrison, R. M. (2002, Winter). Higher fruit consumption linked with lower Body Mass Index. USDA Economic Research Service, FoodReview, 25(3), 28-32.

Lorson, B. A., Melgar-Quiñonez, H. R., \& Taylor, C. A. (2009, March 1). Correlates of fruit and vegetable intakes in US children. Journal of the American Dietetic Association, 109, 474-478. doi:10.1016/j.jada.2008.11.022

Muñoz, K. A., Krebs-Smith, S. M., Ballard-Barbash, R., \& Cleveland, L. E. (1997). Food intakes of U.S. children and adolescents compared with recommendations. Pediatrics, 100(3), 323-329. doi:10.1542/peds.100.3.323

National Center for Education (NCE). (2008). National Center for Education statistics, table 87: Number of public school districts and public and private elementary and secondary schools 1869-2007. Retrieved from http://nces.ed.gov/programs/ digest/d08/tables/dt08 087.asp

National Survey of Children's Health (NSCH). (2008). 2003 Childhood obesity state report cards. National Initiative for Children's Healthcare Quality, Child Policy Research Center, and Child and Adolescent Health Measurement Initiative. Retrieved from
http://www.nschdata.org:80/Content/ ObesityReportCards.aspx

Ogden, C. L., Carroll, M. D., Curtin, L. R., Lamb, M. M., \& Flegal, K. M. (2010). Prevalence of high body mass index in U.S. children and adolescents, 20072008. Journal of the American Medical Association, 303(3), 242-9. doi:10.1001/jama.2009.2012

Ogden, C. L., Carroll, M. D., \& Flegal, K. M. (2008). High body mass index for age among U.S. children and adolescents, 2003-2006. Journal of American Medical Association, 299(20), 2401-5

Ohmart, J., \& Feenstra, G. (2004). Plate tectonics: Do farm-to-school programs shift students diets? Sustainable Agriculture, 16(3), 1-3.

Penland, J. G. (2006). Dietary Reference Intakes (DRIs) - New Dietary Guidelines Really Are New! USDA Agricultural Research Service "News and Events" online column. Retrieved from http://www.ars. usda.gov/News/docs.htm?docid $=10870$

Pilant, V. B. (2006). Position of the American Dietetic Association: Local support for nutrition integrity in schools. Journal of American Dietetics Association, 106(1), 122-133. doi:10.1016/j.jada.2005.11.006

Rees, G. A., Richards, C. J., \& Gregory, J. (2008). Food and nutrient intakes of primary school meals and packed lunches. Journal of Human Nutrition and Dietetics, 21(5), 420-427. doi:10.1111/j.1365-277X.2008.00885.x

Sharma, M. (2006). School-based interventions for childhood and adolescent obesity. Obesity Reviews, 7, 261-269. doi:10.1111/j.1467-789X.2006.00227.x

Trochim, W. (2006). Qualitative methods [Research Methods Knowledge Base version]. Retrieved from http://www.socialresearchmethods.net/kb/ qualmeth.php

U.S. Department of Agriculture (USDA). (2005). MyPyramid.gov: Steps to a healthier you. Retrieved from http://www.mypyramid.gov

U.S. Department of Agriculture (USDA). (2007, November). School Nutrition Dietary Assessment StudyIII. Volume I: School foodservice, school food environment, and meals offered and served. USDA Food and Nutrition Service. Retrieved from http://www.fns.usda.gov/ora/menu/published/ cnp/files/sndaiii-vollexecsum.pdf

U.S. Department of Agriculture (USDA). (2010). National School Lunch Program. Food and Nutrition Service Web site. Retrieved from http://www.fns.usda.gov/cnd/Lunch/About Lunch/NSLPFactSheet.pdf

USDA National Institute of Food and Agriculture (USDA NIFA). (2011). Agriculture and Food Research 
Initiative competitive grants program: Childhood Obesity

Prevention. Retrieved from

http://www.nifa.usda.gov/funding/rfas/pdfs/ 11 child obese.pdf

Vermont Agency of Agriculture, Food and Markets (VAAFM). (2009). Farm to school grant program Funded programs. Retrieved from http://www.vermontagriculture.com/education/ farmtoschool/funded.html
Vermont Agency of Agriculture, Food and Markets (VAAFM). (2010). Farm to School Awareness Day celebrated. Retrieved from http://www.vermont. gov/portal/government/article.php?news $=1577$

Vermont Department of Education (VDE). (2010). Programs \& services: School nutrition programs: policy \& administration. Retrieved from http://education. vermont.gov/new $/ \mathrm{html} / \mathrm{pgm}$ nutrition/ school nutrition/policy.html 
Journal of Agriculture, Food Systems, and Community Development ISSN: 2152-0801 online www.AgDevJournal.com 